


\section{Jens Elo Rytter}

\section{Menneskerettighedernes fremmarch efter 1945 \\ - konsekvenser for moderne menneskesyn, demokrati- og retsfilosofi}

Rettens nynormativisering og internationalisering finder vel intetsteds et så prægnant udtryk som i den bemærkelsesværdige udvikling i menneskerettighedsbeskyttelsen siden 1945. Efter Anden Verdenskrig ses såvel internationalt som nationalt en klar og stabil tendens til en øget anerkendelse af og fokus på individets menneskerettigheder. Artiklen skitserer denne udviklings rødder og politiske årsager og reflekterer over udviklingens implikationer for vor tids menneskesyn, demokratiopfattelse og retsfilosofi.

\section{Rids af rettighedsideologiens udvikling fra filosofi til statsret til folkeret}

Efterkrigstidens menneskeretlige udvikling har baggrund i en renaissance for tanken om individets grundlæggende rettigheder. Derfor indleder jeg med en kort omtale af menneskerettighedernes idéhistoriske baggrund, hvorefter jeg beskriver udviklingen i menneskerettighedsideens retliggørelse - først i forfatningsretten og siden også i folkeretten.

Rettighedstankens rodder. Menneskerettighedstanken har idéhistorisk udspring i metafysiske forestillinger om, at mennesket i sin egenskab af menneske er bærer af visse iboende og umistelige rettigheder. Sådanne forestillinger går helt tilbage til oldtidens Grækenland, hvor stoikerne gjorde sig forestillinger om en højere naturlig lov for alle mennesker og dyr, og hvor Aristoteles skrev om en kosmologisk naturret. Ideen om en naturgiven ret blev overtaget af romerretten gennem skribenter som Cicero og Justinian. Herfra blev den senere indarbejdet $\mathrm{i}$ kristendommen, men nu i teologisk form som forestillingen om en højere guddommelig naturret, blandt andet i Aquinas' skrifter.

Oplysningstidens naturretsfilosofi. Ideen om menneskerettigheder, som den kendes i dag, har udspring i oplysningstidens filosofi i 1600-1700 tallet. Menneskerettighedstanken fik her en opblomstring $i$ form af en fornuftbaseret 
naturretsfilosofi om menneskets medfødte og umistelige rettigheder. Denne politiske filosofi havde rødder i nationalstatens fremkomst og borgerskabets krav om, at fyrsten skulle tilkende dem visse grundlæggende rettigheder. Fremherskende i oplysningstidens menneskeretsfilosofi var ideen om "samfundspagten" - en tankekonstruktion, hvorefter folket ved en uskreven kontrakt har overladt magten til fyrsten mod til gengæld at få garanti for fred, lov og orden. Navnlig hos englænderen John Locke antages samfundspagten betinget af, at fyrsten respekterer visse grundlæggende borgerog menneskerettigheder. Ikke mindst Lockes filosofi dannede - sammen med Charles Montesquieus tanker om magtfordeling - udgangspunkt for debatten om konstitutionalisme. Også tyskeren Immanuel Kants fornuftsretlige filosofi og etik, og navnlig hans kategoriske, moralske imperativ, har fået stor betydning for senere menneskeretstænkning. Menneskerettighederne forblev dog indtil langt op i 1700-tallet i store træk et filosofisk postulat uden retlig realitet.

Det er misvisende, når Magna Carta fra 1215 - et frihedsbrev fra den engelske Kong John til lokale baroner, som sikrede adelsstanden visse rettigheder over for kongemagten - undertiden fremdrages som det første menneskerettighedskatalog. Derimod kan det engelske parlaments Declaration of Rights fra 1688 som led i Englands såkaldte "Glorious Revolution" snarere ses som en forløber for konstitutionalismen.

Forfatningstanken (konstitutionalismen). Som forfatningsretligt begreb er menneskerettigheder politisk-historisk forbundet med nationalstatens fremvækst og den demokratisk-frihedsretlige bevægelse i 1700-1800 tallet. Først da blev den politiske menneskerettighedsfilosofi til retlig virkelighed i form af forfatningssikrede grundrettigheder.

Oplysningstidens filosofi udgjorde det ideologiske grundlag for frihedsbevægelsen i Nordamerika og Vesteuropa i slutningen af 1700-tallet og starten af 1800-tallet. Naturretsfilosofien fik derfor også væsentlig indflydelse på formuleringen af de første frie forfatninger - i USA efter Uafhængighedserklæringen af 1776 og i Frankrig efter revolutionen i 1789. I de nye forfatninger grundfæstede man foruden regler om folkestyre også et sæt af umistelige menneskerettigheder. Udviklingen bredte sig fra Frankrig snart til det øvrige Europa. Danmark fik sin første demokratiske forfatning Grundloven - i 1849.

Denne udvikling er - med tyskeren Klaus Sterns ord - udtryk for, at "menneskerettighedsidé og forfatningsidé flyder sammen og resulterer i den grundrettighedsbaserede forfatningsstat" (Stern, 1992, 34). Den historiske sammenhæng mellem menneskerettighedernes retliggørelse og indførelsen af 
demokrati er naturlig, da demokrati- og rettighedstanken hviler på samme grundlæggende menneskesyn: Den græsk-kristne humanistiske etik om respekt for det enkelte menneskes værdighed og autonomi.

I USA forte den ny forfatning allerede i 1803 til etablering af domstolskontrol med individets grundrettigheder. I Europa var der derimod længe en diskrepans mellem den forfatningsideologi, som prægede frihedsrevolutionerne og forfatningsbølgen i Europa, og den forfatningsretlige virkelighed. Her medførte tiltroen til parlamentet og en indgroet mistillid til de konservative domstole, at domstolskontrol med lovgivningsmagten blev anset for udemokratisk og derfor generelt var ikke-eksisterende indtil langt op i 1900-tallet. Retspositivismens indtog i 1800-tallet bidrog yderligere til at lægge rettighedsideologien på is. I slutningen af 1800-tallet og den første halvdel af 1900-tallet var det således karaktetistisk for Europa, at den demokratiske ideologi om "sovereignty of Parliament" og retspositivismen understøttede hinanden i at holde rettighedstanken i skak (Koopmans, 1994, 192; Grewe, 1996, 175).

Efterkrigstidens internationalisering og styrkelse af forfatningsbeskyttelsen. Efter Anden Verdenskrigs afslutning fik rettighedstanken imidlertid en renaissance på verdensplan. Baggrunden herfor var navnlig den erkendelse, at rædselsregimer og flertalsdiktatur, som man før og under Anden Verdenskrig havde set det i Italien og Tyskland, kun kunne undgås i fremtiden, hvis sikringen af individets menneskerettigheder blev indarbejdet som et fundamentalt element i en demokratisk retsstat.

Karakteristisk for udviklingen efter 1945 er, at menneskerettigheder nu ikke længere kun er et forfatningsretligt anliggende, men også beskyttes gennem internationale konventioner. Internationale menneskerettighedskonventioner markerer en nyskabelse inden for folkeretten. Det er en ny slags folkeret, som umiddelbart regulerer forholdet mellem staten og dens egne borgere. Folkeretten har "overtaget" menneskerettighederne fra de nationale forfatninger og gjort dem til et internationalt anliggende (Gulmann m.fl., 1989, 192f). Den stigende internationale menneskerettighedsbeskyttelse er gået hånd i hånd med en styrket beskyttelse af menneskerettighederne i mange landes forfatninger.

På verdensplan markerer etableringen af FN i 1945 en milepæl. FN-pagtens Artikel 1(3) sætter det som et af FNs centrale mål at fremme menneskerettighederne. Som opfølgning herpå vedtog FN i 1948 Verdenserklæringen om Menneskerettigheder. Verdenserklæringen proklamerer menneskerettighedernes universalitet og opregner herefter en række centrale menneskerettigheder. Verdenserklæringen har ikke alene 
dannet grundlag for den efterfølgende vedtagelse af en række universelle menneskerettighedskonventioner i FNs regi; den er også fundamentet for de regionale menneskerettighedskonventioner og har desuden været en vigtig inspirationskilde ved nationale forfatningsrevisioner.

På regionalt europæisk plan blev FNs Verdenserklæring fulgt op i Europarådet med vedtagelse af Den Europæiske Konvention til Beskyttelse af Civile og Borgerlige Menneskerettigheder i 1950 og Den Europæiske Socialpagt i 1961. Navnlig 1950-konventionen har fået central betydning for menneskeretsudviklingen i Europa og fungerer idag som en slags "Europas Bill of Rights". Dette skyldes ikke mindst, at der til konventionen er knyttet et enestående effektivt kontrolsystem: Enhver borger kan klage til Den Europæiske Menneskerettighedsdomstol i Strasbourg, som med bindende virkning for staterne afgør, om staten har krænket sine borgeres rettigheder. Også EU anerkender et tilsvarende sæt af grundrettigheder for individet, som håndhæves af EF-domstolen. Etableringen af effektive internationale kontrolorganer til værn om individets rettigheder betegner et afgørende brud med den praksis, som før 1945 havde grundfæstet sig i mange stater, hvorefter rettighedskontrol ved domstolene vel i princippet eksisterede, men hvor love ikke i praksis blev tilsidesat (Frowein og Peukert, 1996, 8).

På det nationale plan havde erfaringerne fra Nazi-Tyskland og FascistItalien lært Vesteuropa den lektie, at demokrati ikke altid er en tilstrækkelig garanti for individets frihed og værdighed. I efterkrigstiden er der derfor i mange lande vedtaget nye forfatninger med udførlige menneskerettighedskataloger og bestemmelser om domstolskontrol med disse rettigheder - undertiden ved særlige forfatningsdomstole (Brünneck, 1992, 15f).

Italien og Tyskland etablerede $\mathrm{i}$ henholdsvis 1948 og 1951 særlige forfatningsdomstole, som - med udgangspunkt i nye forfatninger - fik til hovedopgave at beskytte individets rettigheder. En række vesteuropæiske stater har siden overtaget forfatningsdomstols-modellen (Starck og Weber, 1986). Mange stater med forfatningsdomstole har en føderal eller regionaliseret struktur; det gælder foruden Tyskland også Belgien, Østrig, Italien og Spanien. Efter murens fald har flere østeuropæiske stater i forbindelse med overgangen til vestligt demokrati indskrevet menneskerettigheder og bestemmelser om forfatningskontrol i forfatningen. Forfatningskontrollen i de nordiske lande, Holland og Luxembourg varetages dog fortsat af de almindelige domstole. Sverige og Finland har i de senere år udbygget forfatningens rettigheder, og $\mathrm{i}$ Finland fik domstolene i 1999 for første gang en vis ret til forfatningskontrol. Kun i Schweiz og Storbritannien har domstolene fortsat ingen adgang hertil i Storbritannien, fordi landet slet ikke har en skreven forfatning.

Selv i Frankrig - det land som om noget traditionelt har hyldet princippet 
om flertallets vilje som forfatningens bærende princip - er rettighedstanken slået igennem efter 1945. Selv om Frankrig med frihedsrevolutionen og 1789-erklæringen om Menneskelige og Borgerlige Rettigheder historisk har været foregangsland for den europæiske konstitutionalisme, har et domstolsværn om menneskerettighederne altid været den franske politiske tradition fremmed. Fransk forfatningsret har lige siden 1791-forfatningen hvilet på Rousseaus filosofi om loven som udtryk for folkesuveræniteten: "la volonté generale". Erfaringer med konservative domstole før revolutionen havde skabt udpræget mistillid til dommere og dommerskabt ret - man skulle ikke have en "gouvernement des juges". Med 1958-forfatningen blev Forfatningsrådet - Conseil Constitutionel - etableret. Det var oprindelig ikke hensigten, at Forfatningsrådet skulle håndhæve menneskerettighederne; men i 1971 fastslog Rådet på egen hånd - helt uventet - sin kompetence til at prøve loves forenelighed med 1789-erklæringens rettigheder. Forfatningsrådet har siden udviklet sig til en slags forfatningsdomstol og har underkendt en række love. Rådets rolle som vogter af menneskerettighederne er nu fast indarbejdet $\mathrm{i}$ fransk forfatningsret (Favoreu, 1990, 72ff; Rivero, 1990, 60ff).

Den europæiske udvikling er vel særlig markant, men afspejler samtidig en global udvikling efter 1945 imod øget fokus på domstolsbeskyttelse af individets rettigheder (Brewer-Cariás, 1989; Tate og Wallinder, 1995). Der er flere årsager hertil: Ideologisk ses en global renaissance for naturretlig tankegang i filosofi, politik og retsvidenskab; strukturelt har demokratiets fremvækst og sejren for den liberale retsstat haft betydning; hertil kommer en stigende kritik af politikerne, kombineret med domstolenes stigende villighed til at gå aktivt ind i rettighedskontrollen (Tate og Vallinder, 1995, 13ff, $27 \mathrm{ff}$ og 516ff).

Det kan forekomme paradoksalt, at man, som ovenfor skitseret, efter 1945 på menneskeretsområdet ser en øget vægt på forfatningsbeskyttelse gå hånd $\mathrm{i}$ hånd med en øget internationalisering og opløsning af skellet mellem national og international ret. Forklaringen er dog nok den enkle, at det nye syn på forfatningen og folkeretten på menneskeretsområdet har et fælles grundlag. Internationaliseringen og den øgede konstitutionalisering af menneskerettighedsbeskyttelsen har et fælles udspring i en ny demokratiskretsstatslig bevidsthed, affødt af verdenskrigens rædsler. De parallelle udviklinger er båret af en ideologi, som overskrider skellet mellem national og international ret (Grewe, 1996, 180).

\section{Menneskerettens menneskesyn - værdighed, frihed og forbundethed med samfundet}

Menneskerettighedsideologien hviler grundlæggende på tanken om individets 
værdi som individ. Med Kants ord er individet aldrig kun et middel, men et mål i sig selv.

For et moderne menneskesyn har det særlig interesse, at der efter 1945 - især affødt af nazisternes ugerninger - ses en udvikling i menneskerettighedsideologien, hvor fokus skifter fra frihed og lighed til det bredere begreb værdighed (Hartlev, 1999, 76).

I USAs Uafhængighedserklæring fra 1776 hedder det, at: '... all men are created equal (..) they are endowed by their Creator with certain inalienable Rights (..) among these are Life, Liberty and the pursuit of Happiness". Den franske Erklæring om Menneskelige og Borgerlige Rettigheder fra 1789 fastslår i Artikel 1, at "Menneskene fodes og forbliver frie og lige i rettigheder...", og i Artikel 2, at "Enhver politisk sammenslutnings mål er bevarelsen af menneskenes naturlige og umistelige rettigheder. Disse er: Fribed, ejendomsret, sikkerbed og ret til modstand mod undertrykkeelse."

FNs Verdenserklæring om Menneskerettigheder fra 1948 hviler derimod på menneskets værdighed som den fundamentale værdi (Eide og Alfredsson, 1999). I Erklæringens præambel udtales, at "anerkendelse af den $i$ mennesket iboende vardighed og af de lige og ufortabelige rettigheder for alle medlemmer af den menneskelige familie er grundlaget for fribed, retfardighed og fred i verden." I samme ånd fastslår den tyske grundlov fra 1949 i Artikel 1, at: "Menneskets vardighed er ukrankelig. Alle statsorganer har pligt til at respektere og beskytte menneskets vardighed." Den menneskelige værdigheds ukrænkelighed danner også indgangsportalen $\mathrm{i}$ udkastet til EUs grundrettighedscharter.

Denne fokus på menneskets værdighed er ikke mindst tydelig i europæisk menneskerettighedstankegang, som derved efter 1945 har bevæget sig (længere) bort fra amerikansk liberalistisk tradition.

Samtidig er europæisk rettighedstænkning i højere grad end den amerikanske præget af ønsket om at afbalancere individuelle rettigheder og hensynet til de kollektive samfundshensyn. Europæisk retskultur er med sine rødder $i$ kristen humanisme lige så lidt baseret på en rent liberal-individualistisk etik som på en autoritær-kollektivistisk etik. Individets rettigheder udfolder sig inden for, og begrænses af, et socialt fællesskab. Beskyttelse af individets og minoriteters menneskerettigheder anses for fundamentalt, men det gør sikringen af det almene vel også. Den enkeltes rettigheder må ikke udfoldes på bekostning af andre eller af almenheden - og vice versa. Denne balancerede rettighedstænkning gennemsyrer den europæiske menneskerettighedsopfattelse.

I den franske Erklæring om Menneskelige og Borgerlige Rettigheder fra 1789 fastslås $\mathrm{i}$ Artikel 4, at: "Fribeden består $i$ retten til at gore alt, som ikke skader nogen andre..." og i Artikel 5: "Loven har kun ret til at 
forbyde de bandlinger, som er skadelige for samfundet". Centrale rettigheder i Den Europæiske Menneskerettighedskonvention som retten til privatliv, religionsfrihed, ytringsfrihed, forsamlings- og foreningsfrihed er undergivet de begrænsninger, som under hensyn til andre og til samfundet må anses for nødvendige i et demokratisk samfund. Den tyske grundlov af 1949 fastslår i Artikel 2: "Enhver har ret til fri udfoldelse af sin personlighed, for sà vidt han ikke kranker andres rettigheder eller handler $i$ strid med den forfatningsmassige orden og sadvaneretten." I en central afgørelse fra 1954 (Entscheidungen des Bundesverfassungsgerichts, Vol. 4, side 7ff (15f)) fastslog Tysklands forfatningsdomstol i samme ånd et kantiansk inspireret menneskesyn som udgangspunkt for forståelsen af grundlovens rettigheder: "Efter Grundlovens menneskesyn er individet ikke isoleret og suverant; Grundloven har tvartimod lost spandingen individ-samfund ved at betragte individet som orienteret mod og knyttet til samfundsfallesskabet, uden derved at antaste individets egetvard. (..) den enkelte må underkaste sig de begransninger $i$ sin handlefribed, som lovgiver vedtager til pleje og fremme af det sociale fallesskab inden for granserne af det efter forboldets karakter generelt rimelige og under forudsatning af, at individets selustandighed derved bevares."

\section{Menneskerettigheder, demokrati og magtfordeling - det materielle demokrati}

Som tidligere beskrevet var et gennemgående træk i de demokratiske europæiske forfatninger før 1945, at man vel på papiret anerkendte en række grundrettigheder for individet, men at parlamentets overherredømme reelt var helt eller tilnærmelsesvis ubegrænset, enten fordi domstolene ikke var givet kompetence til at håndhæve rettighederne over for lovgivningsmagten eller fordi en sådan prøvelsesret nok eksisterede, men i praksis blev anvendt med den yderste tilbageholdenhed under hensyn til parlamentets folkelige mandat. Rousseau's tanke om "la volonté generale" udmøntet i det engelske princip om "Sovereignty of Parliament" var det helt dominerende forfatningsprincip.

Efterkrigstidens menneskerets- og forfatningsudvikling er udtryk for accept af den opfattelse, at statsmagtens legitimitet foruden parlamentarisk demokrati også forudsætter garantier for mindretallets og individets grundlæggende rettigheder. Det politiske flertals overherredømme er nu reelt begrænset derved, at uafhængige - nationale og internationale - domstole effektivt håndhæver individets rettigheder, også over for lovgivningsmagten.

Den Europæiske Menneskerettighedskonvention hviler således ligesom FNs Verdenserklæring på den overbevisning, at demokrati og menneskerettigheder er hinandens forudsætninger. Præamblen til Europarådets statut - som danner grundlaget for Den europæiske Menneskerettighedskonvention - understreger betydningen af retssikkerhed og rettigheder for demokratiet. Deltagerlandene "..bekerefter deres tillid til de andelige 
og etiske vardier, som er deres folks falles arvelod og den sande kilde til personlig fribed, politisk uafhangighed og et styre bvilende på lov og ret-principper, som danner grundvolden for ethvert sandt demokrati". Menneskerettighedskonventionens præambel fastslår omvendt folkestyre som en betingelse for menneskerettighedsbeskyttelse. Det udtales - med henvisning til Verdenserklæringen af 1948 - at deltagerlandene "bekrafter deres dybe tro på disse grundlaggende fribedsrettigheder, som er grundlaget for retfardighed og fred i verden og bedst handhaves af et virkeligt demok ratisk regeringssystem". Denne overbevisning er, som tidligere beskrevet, også slået igennem nationalt $\mathrm{i}$ form af en styrket domstolskontrol med forfatningens menneskerettigheder.

Menneskerettighedsudviklingen har hermed bidraget til en ændring i demokratiopfattelsen i efterkrigstiden fra en overvejende formel forståelse - flertalsstyre er det altdominerende princip og grundrettighedsbeskyttelse hovedsageligt eksisterer på papiret - til en materiel forståelse - flertalsstyret skal respektere forfatningens materielle rammer, som sikres gennem en effektiv grundrettighedsbeskyttelse ved domstolene.

For flere europæiske lande - herunder ikke mindst de nordiske - bryder denne udvikling med det traditionelle syn på domstolenes forfatningsretlige rolle. Også i Danmark inspirerer denne tendens til en øget fokus på menneskerettigheder og til en mere aktiv rolle for domstolene, også i forhold til lovgivningsmagten (Zahle, 1997, 38; Rytter, 2000, 47ff).

\section{Menneskerettens pluralisme og normative fællesskab - domstolenes rolle}

Menneskerettighederne udvikles og håndhæves selvstændigt inden for forskellige normsystemer og af forskellige aktører. Dette muliggør og nødvendiggør en gensidig, frugtbar harmonisering, men indebærer også en risiko for konflikt. Menneskerettighedsudviklingen er således pluralistisk, hvilket også gælder mange andre retsområder. Dette har andre fagområder, som retssociologien, forlængst erkendt, men i retsfilosofien har rettens enhed længe holdt stand som et dogme (jf. kritisk Zahle, 1991).

Pluralismen har både en institutionel og en formel side. Den institutionelle pluralisme betegner eksistensen af en flerhed af kontrolorganer, som fortolker det samme retssystems regler. Denne flerhed af kontrolorganer er først og fremmest en kilde til inspiration mellem kontrolorganerne således, at fortolkningsprincipper og strategier hos den autoritative fortolker forplanter sig til de øvrige fortolkere. Den formelle pluralisme betegner eksistensen af en flerhed af retssystemer, som har kompetence til at regulere samme retsområde. Flerheden af retssystemer - den nationale forfatningsret, fællesskabsretten og Menneskerettighedskonventionen - indebærer ikke alene en inspirationsmulighed og et harmoniseringsbehov, men også en risiko for konflikt. Individernes retsstilling reguleres inden for forskellige, autonome 
retssystemer med selvstændige kontrolorganer, og efter det enkelte retssystems selvforstålse skal dets egne regler have ubetinget gyldighed for individets retsstilling. I det omfang kravene fra de enkelte retssystemer viser sig uforenelige, opstår en konflikt mellem retssystemerne. Denne konflikt har ikke én korrekt retlig løsning, men flere. Løsningen afhænger af, hvilket forum der skal tage stilling til konflikten, da hvert retssystem prætenderer at have forrang for de andre (Zahle, 1995, 188 og 196ff; Rytter, 1998b, 22f).

Der tegner sig imidlertid i Europa konturerne af en fælleseuropæisk forfatningstænkning med fælles demokratiske principper og - navnlig - en fælles standard for beskyttelse af individets rettigheder (Brünneck, 1992, 125ff; Stern, 1992., 33f; Rytter, 2000, 58f).

Denne udvikling befordres af et fælleseuropæisk rettighedskompleks Den Europæiske Menneskerettighedskonvention - og en gradvis tilnærmelse af de forfatningsretlige rettighedskataloger. Hertil kommer, at den traditionelle retskildelære med sit udgangspunkt $\mathrm{i}$ nationalstatens suverænitet og et dualistisk syn på forholdet mellem national og international ret i stigende grad anses for utilstrækkelig som forståelsesramme for den påvirkning, som den nationale ret udsættes for fra andre retssystemer (Espersen, 1970, 163; Koopmans, 1994, 189ff; Zahle, 1996a, 134; Öhlinger, 1997). Tendensen til udviskning af sondringen mellem national og international ret er særlig udtalt på menneskerettighedsområdet, hvor den internationale ret regulerer retsstillingen for statens individer. De internationale menneskerettigheder slår igennem nationalt (Rytter, 2000, 110f).

Afgørende for den fælleseuropæiske rettighedsudvikling har dog frem for alt været domstolenes retsskabende rolle i fortolkningen og udviklingen af menneskerettighedsbeskyttelsen. Den spirende fælleseuropæiske rettighedsstandard er affødt af en stadig mere homogen domstolsfortolkning og af fælles retfærdighedsforestillinger, som transcenderer grænser mellem stater og retssystemer (Kirchhof, 1994, 33; Rytter, 1998b, 21; Koch, 1999, 226f). Rettighedsfortolkningen trækker på et fællesskab om fundamentale retfærdighedsforestillinger, som er forankret i den europæiske kultur og historie. Dette værdifællesskab overvinder i vidt omfang de tekstuelle forskelle, som fortsat består mellem retssystemerne. Bag de positive rettighedstekster findes fælleseuropæiske retsgrundsætninger. Sådanne retsgrundsætninger kan finde anerkendelse enten som led i fortolkningen af en positiv bestemmelse eller som uskrevent menneskeretligt princip. For en rettigheds anerkendelse er en positiv retsfastsættelse ikke altid altafgørende (Häberle, 1991, 269; Koch, 1997, 340).

Beskyttelsen af individets grundlæggende rettigheder udvikler sig derfor $\mathrm{nu} \mathrm{i}$ en kompleks vekselvirkning mellem de overnationale domstole - 
Menneskerettighedsdomstolen i Strasbourg og EF-domstolen i Luxembourg - og de nationale domstole (se nærmere Rytter, 1998a). Den stigende grad af påvirkning sker i vidt omfang på det praktiske plan, uden formelle ændringer af den internationale rets forfatningsretlige status. Ved konkretiseringen af grundretlige principper inspireres den ene domstol af den anden domstols praksis. Denne indirekte påvirkning, hvor en domstols fortolkningsprincipper og grundsætninger forplanter sig til andre domstoles fortolkning af egne grundrettigheder, kan betegnes som praktisk monisme eller fortolkningsmonisme (Espersen, 1970, 163; Zahle, 1996b, 268; Rytter, 1998b, 24f).

Denne harmonisering gennem fortolkning har som sin forudsætning en stigende grad af homogenitet i principperne for grundrettighedsfortolkning og -kontrol: En generel åbenhed over for anerkendelse af uskrevne grundretlige principper og en tendens til en formålsorienteret og dynamisk fortolkningsstil. Anerkendelsen af en mere fri og dynamisk fortolkning ved europæiske domstole er udtryk for, at den kontinentaleuropxiske "code law"-tradition på menneskerettighedsområdet er under indflydelse af den angelsaksiske "case law"-tradition (Häberle, 1991, 269; Koch, 1997, 337). Det anerkendes i stigende omfang, at domstolene ikke blot håndhæver rettigheder, men også skaber ny ret gennem deres fortolkning (Koopmans, 1994, 194f).

\section{Menneskerettigheder, moral og retsfilosofi}

I forhold til andre samfundsvidenskaber har retsvidenskaben været karakteriseret ved en forbavsende kontinuitet. Ifølge Dahlberg-Larsen kan i de seneste 200 års retsvidenskab konstatere et fravær af egentlige paradigmeskift, hvilket ellers har præget de andre samfundsvidenskaber (Dahlberg-Larsen, 1977, 82ff). Den analytiske tradition med sit naturvidenskabelige, empiriske ideal har præget retsvidenskaben i de sidste 200 år. Det er således betegnende, at ordet retsvidenskab fra omkring år 1800, inspireret af Savigny, afløste den hidtidige betegnelse jurisprudens - retskyndighed (Dahlberg-Larsen, 1977, 81, jf. 185f).

Der er imidlertid en stigende anerkendelse også herhjemme af, at retsvidenskaben må frigøre sig fra dette ideal, retsvidenskabens genstand er et normativt system, og for at være en handlingsorienteret videnskab må retsvidenskabsmanden derfor også engagere sig retspolitisk (Dahlberg-Larsen, 1977, 545ff; Rytter, 2000, 80ff med yderligere henv.). Det gælder ikke mindst på menneskerettighedsområdet. Menneskerettighedsudviklingen har i sig selv styrket den normativistiske retsfilosofi og dogmatik. Menneskerettighederne tilbyder et værdigrundlag for retsvidenskab og retsanvendelse. Retsvidenskaben er således omsider - omend forsinket i forhold til andre åndsvidenskaber - ved at forlade den logiske positivistisme som sit filosofiske grundlag og analysen 
som sit eneste værktøj. Retsvidenskaben er på vej tilbage til retskyndigheden.

I de senere årtier er tendensen i retsfilosofien således gået fra en positivistisk funderet, funktionalistisk eller realistisk retslære imod en mere normativistisk, herunder naturretligt inspireret, retstænking. Det gælder også i Danmark, illustreret ved følgende - omend indbyrdes vidt forskellige - værker: Peter Høilund, Den forbudte retsfølelse fra 1992; Henrik Palmer Olsen, Rationalitet, Ret og Moral fra 1997 og Alexander Carnera Ljungstrøm, Rettens Alkymi - Om venskab, retfærdighed og pathos fra 1998.

Menneskerettighedstanken har baggrund i det humanistiske grundprincip om individets værdi som individ. Dette princip har sit historiske udspring i oplysningstidens politiske naturretsfilosofi. Det synes derfor logisk, at naturretsfilosofien internationalt har fået en renaissance $i$ takt med, at menneskerettighedsbeskyttelsen har vundet frem. Filosoffer som John Rawls (A Theory of Justice, 1972) Robert Nozick (Anarchy, State and Utopia, 1974) og John Finnis (Natural Law and Natural Rights, 1980) har formuleret anerkendte rettighedsteorier, som er baseret på ideer om en objektiv og almengyldig retfærdighed.

En normativistisk retsfilosofi er dog ikke nødvendigvis ensbetydende med en anerkendelse af naturretten. Der findes således en række anerkendte normativistisk retsteorier, som afviser såvel den logiske positivisme og den pragmatiske realisme som den objektiverede naturret til fordel for en relativistisk, kontekstuel idealisme inden for en hermeneutisk forståelsesramme. Det gælder f.eks. amerikaneren Ronald Dworkin (Law's Empire, 1986) og den nyligt afdøde nordmand David Doublet (Rett, Vitenskap og Fornuft, 1995).

I dag kan vi forstå og begrunde princippet om individets værdi qua individ uden at måtte henvise til naturretlige konstruktioner. Vort menneskesyn er en kulturelt betinget etik, der står centralt i den vestlige verdens politiske, sociale, religiøse og retlige bevidsthed. Pointen kan illustreres med de internationale menneskerettigheder: Verdenserklæringen om Menneskerettigheder fra 1948 postulerer i præamblen, at menneskerettighederne er universelle. Dette postulat ses ofte som udtryk for rationalistisk naturretsfilosofi. Efter min opfattelse kan Verdenserklæringens postulat om universalitet dog lige så vel forstås $i$ et kulturelt, historisk lys, hvor den naturretlige retorik om "menneskets iboende værdighed" og "ufortabelige rettigheder" blot er midler til at styrke det politiske budskab om universel respekt for visse grundlæggende rettigheder - rettigheder, som er formuleret på grundlag af europæisk idéhistorie og som reaktion på Anden Verdenskrigs overgreb. En retlig argumentation for menneskerettighedernes universalitet forudsætter dermed ikke et moralfilosofisk udgangspunkt i naturretten, men kan forstås som en påstand $\mathrm{om}$, at Verdenserklæringen (nu) er udtryk for almindelig folkeretlig norm (i 
samme retning Kjærum, 1997, 61).

Menneskerettighedsudviklingens implikationer for opfattelsen af retten er dog endnu langt fra slået fuldt igennem i retsfilosofien og retsdogmatikken. Man kan skitsere menneskerettighedsudviklingens konsekvenser for retten ved at holde denne udvikling op imod én af det forgangne århundredes mest anerkendte og indflydelsesrige retsfilosofier: Østrigeren Hans Kelsens "rene retslære" (hovedværket Reine Rechtslehre, 1933).

Kelsen ville gøre retsvidenskaben empirisk - gøre den "ren". Kelsen betragtede retten som et system af positive (anvendte) normer. Retsvidenskabens rolle er ifølge Kelsen alene at fastslå, hvilke normer, der er gældende ret, uden at vurdere disse normer ud fra en moralsk eller politisk målestok og uden skelen til de sociale virkninger af en fastlagt retstilstand. Kelsens tilgang er analytisk - retsvidenskaben anskues som en logisk begrebsvidenskab. Han betegner retssystemet som et hierarkisk normsæt, ordnet $i$ en pyramide af normtyper, hvis gyldighed afledes af normtypen ovenover. Øverst i hierarkiet - over forfatningen - findes grundnormen, som imidlertid ikke er en positiveret norm, men en slags hypotetisk metanorm, som forudsættes i juridisk tænkning. Som følge af sit ideal om én grundnorm for retssystemet måtte Kelsen nødvendigvis også opfatte forholdet mellem national ret og folkeretten som monistisk - som ét retssystem underordnet én grundnorm, som må findes i folkeretten - i modsætning til den da herskende dualistiske opfattelse om national ret og folkeretten som to adskilte retssystemer. Kelsens rene retslære har afgørende præget det 20. århundredes kontinentaleuropæiske retstænkning - herunder ikke mindst den skandinaviske retsrealisme og denne retnings hovedskikkelse Alf Ross (Om Ret og Retfærdighed, 1953).

Kort fortalt har menneskerettighedsudviklingen efter 1945 bidraget til at afkræfte forestillingen om, at retten udtømmende kan beskrives som de positive normer og at nedbryde tanken om det pyramidiske regelhierarki; men den har samtidig styrket tanken om national ret og folkeret som en retlig enhed. Med grundnormen er det vanskeligere. Grundnormen var af Kelsen ment som en hypotetisk, begrebsmæssig størrelse. Det pudsige er, at virkeligheden i dag er den, at menneskerettighederne er slået igennem som grundnormer for retten som helhed. Hvor efterkrigstidens menneskerettighedsudvikling således nok har medvirket til at dekonstruere rettens formelle, bierarkiske enhedlegitimeret ved og baseret på en tænkt grundnorm - har den således samtidig bidraget til at rekonstruere rettens normative, vardimassige enhed. For så vidt er Kelsens logisk-teoretisk funderede forestilling om et retssystem, afledt af én grundnorm og med en monistisk sammenhæng mellem national ret og folkeret, på en forunderlig måde ved at blive en praktisk realitet i kraft 
af menneskerettighedsudviklingen. De grundlæggende menneskerettigheder repræ-senterer i dag retlige grundværdier, som transcenderer såvel den positive, hierarkiske ret som grænserne mellem stater og det traditionelle suverænitetsbegreb. Denne udvikling har dog ikke baggrund i et ideal om begrebslogisk renhed, men $i$ et fælles værdigrundlag baseret på grundforestillingen om individets ukrænkelige værdighed .

Lad mig blot give to eksempler fra menneskerettighedsområdet, som illustrerer, at moralen er til stede i retten og endog kan overtrumfe/transcendere den skrevne ret.

Efter Anden Verdenskrigs afslutning oprettede de sejrende magter internationale militærtribunaler i Nürnberg og Tokyo med henblik på at retsforfølge personer fra de europæiske aksemagter og Japan, som var ansvarlige for bl.a. "forbrydelser mod menneskeheden". Denne forbrydelse var ikke tidligere nedfældet $\mathrm{i}$ internationale konventioner, men blev under retsopgøret anset for uskreven folkeret. Nazisternes gerninger var efter det internationale samfunds opfattelse så modbydelige, at de måtte straffes. Moral blev med andre ord gjort til ret. Således afviste Nürnberg Tribunalet i sin dom fra 1946 alle indvendinger imod retssagen med bl.a. følgende udtalelse: "international law imposes duties and liabilities upon individuals as upon states (...) the very essence of the Charter [Tribunalets statut] is that individuals have international duties which transcend the national obligations of obedience imposed by the individual state." (citeret efter Brownlie, 1998, 566). Der går herfra en lige linje til den engelske højesterets - House of Lords - beslutning i 1999 om at udlevere Chiles ex-diktator Pinochet til retsforfølgning for tortur og forbrydelser mod menneskeheden, trods Pinochets lovmæssige immunitet som tidligere statsoverhoved. Rettens begrundelsen var, at grove menneskeretskrænkelser aldrig kan være en legitim del af en statsleders virke. Statens suverænitet giver ikke (længere) et retligt værn for menneskerettighedsforbrydere.

I en sag for Norges Høyesterett fra 1983 (Norsk Retstidende 1983, side 1004ff (1017f)) gjorde en borger gældende, at en netop vedtaget lov om fri abort var i strid med en uskreven forfatningsretlig grundsætning om retten til liv. Retten afviste, at abortlovgivningen var forfatningsstridig. Imidlertid udtalte den førstevoterende dommer indledningsvis på hele rettens vegne: "Teg anser det $i$ og for seg for klart, at kravet om respekt for menneskelivet, også det ufodte liv, er at av de rettsprinsipper som vil kunne anses overordnet den positive lovgivning."

Disse eksempler illustrerer, at moral - som det er blevet udtrykt udgør det dybeste lag i rettens, og da navnlig mennesskerettens, "arkæologi" (Eriksson, 1990, 24). Retsbegrebet kan derfor aldrig renses for moralfilosofi - eller politisk filosofi og sociologi for den sags skyld - med mindre man (som Kelsen?) er villig til at betale prisen for en sådan "ren" retslære: At det 
videnskabelige retsbegreb ikke svarer til virkelighedens ret.

\section{Menneskerettigheder, ret og idéhistorie}

Der har utvivlsomt altid været mere åndelig og moralsk spræl i den virkelige ret, end den positivistiske og analytiske retsvidenskab har villet anerkende. Den kunstige ydre legitimering af retlig fortolkning som en uinteresseret retsanvendelsesproces er menneskerettighederne med til definitivt at nedbryde. Retten - retsanvenderen, retsdogmatikeren og retsfilosoffen - må nu stå frem og åbent vedkende sig sin karakter, sine værdier og sit samfundsmæssige ansvar.

Menneskerettighederne - og i deres centrum forestillingen om menneskets værdighed - er blevet normative holdepunkter for en ny, samlende forståelse af retten, på tværs af regelhierarkier og landegrænser, og for en værdi- og dermed handlingsorienteret retsvidenskab.

I den forbindelse har retsvidenskaben og idéhistorien en vigtig fælles opgave: At sammenholde moderne menneskerettighedstænkning og-udvikling med ideerne hos oplysningstidens koryfæer udi politisk og etisk filosofi. Hvad kan vi bruge deres tanker til i dag?

\section{Litteraturliste:}

Brewer-Cariás, Allan R.: (1989) Judicial Review in Comparative Law, Cambridge University Press, Cambridge.

Brownlie, Ian: (1998) Principles of Public International Law, Clarendon Press, Oxford.

Brünneck, Alexander von: (1992) Verfassungsgerichtsbarkeit in den westlichen Demokratien, Nomos Verlagsgesellschaft, Baden-Baden.

Dahlberg-Larsen, Jørgen: (1977) Retsvidenskaben som samfundsvidenskab, Juristforbundets Forlag, København.

Eide, Asbjørn og Gudmundur Alfredsson: (1999) "Introduction" i Alfredsson og Eide (eds.), The Universal Declaration on Human Rights, Kluwer, Haag, side xxv-xxiii.

Eriksson, Lars D.: (1990) "Retfærd - fortid og framtid", Retfard 1990, side $18 \mathrm{ff.}$

Espersen, Ole: (1970) Indgållse og opfyldelse af traktater, København.

Favoreu, Louis: (1990) "Menneskerettighetserklæringen av 1789 og det franske forfatningsråd", Tidsskerift for Retsvitenskap 1990, side 72ff.

Frowein og Peukert: (1996) Europäische Menschenrechtskonvention, Engel Verlag, Kehl. 
Grewe, Constance: (1996) "Statsforfatningsrettens aktualitet i Europa - eller renessansen for en rettsdisiplin", Lov og Rett 1996, side $172 \mathrm{ff}$.

Gulmann, Claus m.fl.: (1989) Folkeret, Jurist- og Økonomforbundets Forlag, København.

Hartlev, Mette: (1999) “Beskyttelse af den menneskelige værdighed” i Grundlovens nutid og fremtid, Årsberetning 1998 fra Retsvidenskabeligt Inst. B, Kbh. Universitet, side $75 \mathrm{ff}$.

Häberle, Peter: (1991) “Gemeineuropäisches Verfassungsrecht”, Europäische Grundrechte-Zeitschrift 1991, side $261 \mathrm{ff}$.

Kirchhof, Paul: (1994) "Verfassungsrechtlicher Schutz und internationaler Schutz der Menschenrechte”, Europäische Grundrechte-Zeitschrift 1994, side $16 \mathrm{ff.}$

Kjærum, Morten: (1997) "Menneskerettigheder i et udvidet Europa og en globaliseret verden” i Kjærum m.fl. (red.), Menneskerettigheder og Grundloven, Jurist- og Økonomforbundets Forlag, København, side 45ff.

Koch, Henning: (1997) "Dommerret - om forfatningsdomstol, menneskeretitghederog overpositiv ret i Tyskland" i Kjærum m.fl (red.), Grundloven og menneskerettigheder, Jurist- og Økonomforbundets Forlag, København, side $325 \mathrm{ff}$.

Koch, Henning: (1999) "Dansk forfatningsret i transnational belysning", Juristen 1999 , side $213 \mathrm{ff}$.

Koopmans, Thijmen: (1994) "Sources of Law - the New Pluralism" i Liber Amicorum Ole Due, GADs Forlag, København, side 189ff.

Rivero, Jean: (1990) “Menneskerettighetenes stilling i fransk ret fra 1789 til 1971”, Tidsskrift for Retsvitenskap 1990, side 60ff.

Rytter, Jens Elo: (1998a) "Den europæiske menneskerettighedsudvikling - samspillet mellem nationale og overnationale domstole" i Arsberetning 1997 fra Retsvidenskabeligt Institut B, Kbh. Universitet, side $175 \mathrm{ff}$.

Rytter, Jens Elo: (1998b) "Den åbne forfatningsstat - forfatning, menneskerettigheder og inter/overnational ret”, Retfard 1998, side $19 \mathrm{ff}$.

Rytter, Jens Elo: (2000) Grundrettigheder. Domstolenes fortolkning og kontrol med lovgivningsmagten, Forlaget Thomson, København.

Starck, Christian og Albrecht Weber (udg.): (1986) Verfassungsgerichtsbarkeit in Westeuropa, Nomos Verlagsgesellschaft, Baden-Baden. 


\section{Jens Elo Rytter}

Stern, Klaus: (1992) "Idee der Menschenrechte und Positivität der Grundrechte" i Isensee og Kirchhof (udg.), Handbuch des Staatsrechts, Band V: Allgemien Grundrechtslehren, C.F. Müller Juristischer Verlag, Heidelberg, 1992, \108, side $3 \mathrm{ff}$.

Tate, C. Neal og Torbjörn Vallinder (red.): (1995) The Global Expansion of Judicial Power, New York University Press, New York.

Zahle, Henrik: (1991) "Seks teser om den retlige pyramide” i Blume m.fl. (red.), Suum Quique, Retsvidenskabelige afhandlinger Københavns Universitet 1991, Juristog Økonomoforbundets Forlag, København, side 50ff.

Zahle, Henrik: (1995) “The Polycentricity of the Law or the Importance of Legal Pluralism for Legal Dogmatics" i Petersen m.fl. (red.), Legal Polycentricity: Consequences of Pluralism in Law, Dartmouth, Aldershot, side $185 \mathrm{ff}$.

Zahle, Henrik: (1996a) “On Polycentrism and Legal Pluralism or: Does a Concept such as Danish Constitutional Law exist?” i Arnfred og Petersen (udg.) Legal Change in a North/South Perspective, Roskilde Universitet, side $131 \mathrm{ff}$.

Zahle, Henrik: (1996b) Dansk forfatningsret, Bind 2: Regering, forvaltning og dom, Christian Ejlers Forlag, København, 1996.

Zahle, Henrik: (1997) Dansk forfatningsret, Bind 3: Menneskerettigheder, Christian Ejlers Forlag, København, 1997.

Öhlinger, Theo: (1997) "Unity of the Legal System or Legal Pluralism: The Stufenbau Doctrine in Present Day Europe”, paper fremlagt på Round Table i the International Association of Constitutional Law afholdt i Åbo, Finland, maj 1997. 